definition and its simplicity in the arrangement of the vocabulary for rapid reference. The book is divided into three parts, of which the first is devoted to the systematization of simple and compound medical terms; the second, to hygienic, medical, surgical and domestic affairs; Part 3 , consists of dialogues, idiomatic phrases and proverbs, a schedule of the termination of each declension, and a list of irregular verbs. Medical students will find much of value in this volume, and it should find a place upon the shelves of every reference library.

\section{SOCIETY NEWS.}

Southwestern Iowa Medical Association.-The semi-annual meeting of the Southwestern Iowa Medical Association was held in Red Oak, Iowa, August 15. Attendance sixty.The physicians of Douglas County, Kansas, met at Lawrence, Kan., August 10, and formed a society. The following officers were elected: President, W. S. Bunn; Vice President, J. I. Douthart; Secretary, H. Ernest.

Mississippi Valley Medical Association.-The secretary of this Association desires to announce that the railroad rates for the Detroit meeting September $3,4,5$ and 6 will be one and one-third regular fare, on the certificate plan. In purchasing ticket to Detroit full fare will be paid. On request, the local ticket agent will furnish purchaser with certificate which will be handed to the secretary at Detroit. This certificate when signed and vised by the agent of the Central Traffic Association will entitle holder to a return ticket at one-third regular fare. Frederick C. Woodburn, Secretary.

American Academy of Railway Surgeons.-The second annual meeting will be held in the parlors of the Auditorium Hotel, Chicago, Ill., on Wednesday, Thursday and Friday, Sept. 25 , 26 and 27,1895 . Motto: "The higher the order of Railway Surgery, the greater the protection to the Employe, the Passenger and the Company." Officers: President, C. K. Cole, Chief Surgeon, Mont. Cent. R'y, Helena, Mont.; First VicePresident, C. M. Daniels, Chief Surgeon, W. N. Y. \& P. R'y, Buffalo, N. Y.; Second Vice-President, W. H. Elliott, Chief Surgeon, Cent. R'y of Georgia, Savannah, Ga.; Secretary, Webb J. Kelly, Surgeon, Erie \& Big Four R'ys, Galion, Ohio ; Treasurer, C. B. Kibler, Surgeon, Erie R'y, Corry, Pa.; Editor R. Harvey Reed, Consulting Surgeon, B.\& O. R'y, and Surgeon, C. S. \& H. R. R., Columbus, Ohio ; Chairman of Executive Board, John E. Owens, Chief Surgeon. C. \& N. W. R'y Chicago, Ill.; Chairman of Committee on Transportation, W. J. Galbraith, Chief Surgeon, U. P. R'y, Omaha, Neb.; Chairman of Committee on Arrangements, A. D. Bevan, Chief Surgeon, Iowa Central R'y, Chicago, Ill.

First Session-Wennesday.

Subject unannounced, R. D. Mussey, Chief Surgeon, C. H. \& D. R'y, Cincinnati, Ohio.

Some of the Benefits to be derived from the Higher Order of Railway Surgery, W. J. Galbraith, Chief Surgeon, U. P. R'y, Omaha, Neb.

Subject unannounced, A. D. Bevan, Chief Surgeon, Iowa Cent. R'y, Chicago, Ill.

Subject unannounced, M. Cavana, Surgeon, N. Y. P. \& O. R'y, Oneida, N. Y.

Subject unannounced, W. H. Buechner, Surgeon, Erie R'y Cleveland, Ohio.

Second Session-Wednesday.

President's Address, C. K. Cole, Chief Surgeon, Mont. Cent. R'y, Helena, Mont.

Report of Secretary. Treasurer and Standing Committees. Registration of Fellows and payment of dues. Consideration and disposal of applications for fellowship. Miscellaneous business.

Third Session-Thursday.

Subject unannounced, J. W. Perkins, Surgeon, U. P. R'y Kansas City, Mo.
Fractures of the Forearm Complicated with Dislocation, E. Griswold, Surgeon, Erie R'y, Sharon, Pa.

Subject unannounced, Wm. T. Dalby, Ass't Surgeon, U. P. R'y, Salt Lake City, Utah.

Subject unannounced, F. H. Peck, Surgeon, N. Y. P.\& O. R'y, Utica, N.Y.

Fovrtil Session-Thursday.
Address on Medico-Legal Surgery, Hon. Tracy C. Becker, Buffalo, N. X.

A Practical Way of Testing Railway Employes for Color Blindness, D. C. Bryant, Oculist, U. P. R'y, Omaha, Neb.

Traumatic Neurosis, Henry W. Coe, Surgeon, East side R'y, Portland, Ore.

Verdicts Obtained Through Perjury, C. B. Kibler, Surgeon,

N. Y. P. \& O. R'y, Corry, Pa.

What Should Disqualify Applicants for Railway Service John E. Owens, Chief Surgeon, C. \& N.W. R'y, Chicago, Ill.

Personal Experience in Spinal Injuries, J. M. Pritchard, District Surgeon, C. \& N. W. R'y, Manitowoc, Wis.

Intra-Venous Injection of Neutral Salt Solution in the Treatment of Desperate Injuries. Exhibition of Apparatus, C. B. Parker, Surgeon, L. S. \& M. S. R'y, Cleveland, Ohio.

$A$ Word on the Modern Use of the Terms Infection and Contagion, R. Harvey Reed, Consulting Surgeon, B. \&. O. R'y, Columbus, Ohio.

Fifth Session-Friday.

Railway Sanitation, W. M. Bullard, Ass't Surgeon, Mont. Cent. R'y, Wickes, Mont.

Sanitary Regulations Governing Railways, L. E. Lemen, Division Surgeon, U. P. R'y, Denver, Colo.

The Use of Gold Foil in Fractures of the Cranium and Resulting Hernia Cerebri, W. L. Estes, Chief Surgeon, L. V. R'y, S. Bethlehem, Pa.

$$
\text { Sixth Session-Friday. }
$$

Transportation of Injured Employes, F. H. Caldwell, Chief Surgeon, S. F. \& W. R'y, Sanford, Fla.

The Use of Cocain in Minor Amputations, C. M. Daniels, Chief Surgeon, W. N. Y. \& P. R'y, Buffalo, N. Y.

Concussion of the Brain,W.H. Flliott, Chief Surgeon, Ga. Cent. R'y, Savannah, Ga.

Wounds that Open the Knee-Joint-Treatment, C. D. Evans, Surgeon, U.P. and B. \& M. R'y, Columbus, Neb.

Treatment of Wounds of Face and Scalp, Charles B. Fry, Surgeon, Big Four R'y, Mattoon, Ill.

Injuries of the Hands and Fingers, John MeLean, Chief Surgeon, P. P. C. Co., Pullman, Ill.

How to Differentiate Between the Use of Heat and Cold in Railway Injuries, Wm. Mackie, Surgeon, C. M. \& St. Paul R'y, Milwaukee, Wis.

Best Method of Obtaining the best possible Aseptic Condition during Operation done at places other than Hospitals, J. F. Reger, Surgeon, B. \& O. R'y, Littleton, West Va. Seventh Session-Friday.

Selection of next place of meeting. Miscellaneous business. Introduction of officers elect. Adjournment.

The managers of the various railroads that have already reported, have very cordially agreed to furnish the necessary transportation to enable the Fellows of the Academy to attend the coming meeting. Those who need transportation will apply for same at once through their proper officers. Very respectfully submitted,

\section{W. J. Galbraith, Chief Surgeon, U. P. R'y, Omaha, Neb.}

Medical Society of Virginja.-The twenty-sixth annual session of the Medical Society of Virginia will be held in Wytheville, Va., beginning Sept. 3, 1895. After prayer, Address of Welcome by CoL. R. E. Withers, M.D., Report of Committee on Applications for Fellowship, etc., the Address to the Public and Profession will be delivered by Dr. Lewis G. Pedigo, Shawsville, Va.

Report of Committee on Prize Essays: Dr. Hunter McGuire's prize of $\$ 100$ for essay on "The Present Status of Serum-Therapy;" conjoint prize of Drs. Joseph Price and Herbert M. Nash of $\$ 200$, for "The History of Surgery and of Surgeons in Virginia."

Wednesday, September 4, Dr. Ro. J. Preston, of Marion, Va., will deliver the Annual Address of the President.

After the elections, etc., the call for papers and discussions will be continued as the order of business. The following Fellows have complied with the terms of their appointment by the President last fall.

Z. V. Sherrill, Bland Court House, Vesical Calculus in 
Females; James N. Greer, St. Paul, Laparotomy, with Report of Cases ; C. K. Kernan, Lebanon, Strychnia as a Heart Tonic; W. S. Sayers, W y theville, Convulsions; George Ben. Johnston, Richmond, Treatment of Cholelithiasis; J. W. Long, Richmond, Pelvic Inflammations; T. W. Simmons, Martinsville, Uric Acid as a Gynecologic Factor; Wm. F. Drewry, Petersburg, State Provision for Epileptics; Hugh M. Taylor, Richmond, Obstruction of Bowels; Paulus A. Irving, Richmond, Puerperal Sepsis.

The following have promised papers: Honorary Fellow Dr. Hunter McGuire, Richmond, Seventeen Operative Cases of Chronic or Relapsing Appendicitis, with One Death-Remarks - B. C. Keister South Boston, Varicocele; J Allison Hodges, Richmond, The Galvanic Current in Treatment of Pelvic Pain; Honorary Fellow Dr. Joseph Price, Philadelphia, Pa.; R. M. Slaughter, Theological Seminary, Abscess of the Liver in Children; James I. Kent, Bertha, Long Survival of Injury of the Spinal Cord in the Cervical Region; Charles M. Blackford, Lynchburg, Pathology and Treatment of Gonorrhea; Honorable Fellow George Tucker Harrison, New York, The Symptomatology, Etiology and Treatment of Endometritis; M. J. Payne, Locust Grove, A Case of Cerebral Trauma, Indistinct and False History-Remarks on Diagnosis and Treatment; Jos. A. White, Richmond, Ege Troubles in their relation to Diseases of Other Organs.

The following have responded favorably: J. MeFadden Gaston, Atlanta, Ga., Pyemia and Septicemia in their Surgical Aspects ; D. Mayer, Charleston. W. Va., Rigid Os; Edwin Ricketts, Cincinnati, Ohio, Some Recent Work in GallBladder Surgery.

LaNdon B. Enwards; M.D.

Recording Secretary, etc. (for the Executive Committee). Richmond, Va., Aug. 3, 1895.

\section{PUBLIC HEALTH.}

To Prevent Blindness.-Two laws precisely alike were passed by the last General Assembly at its regular session and signed by the Governor of Illinois, namely, House Bill No. 51 and Senate Bill No.57. They provide that should any midwife or nurse having charge of an infant in this State notice that one or both eyes of such infant are inflamed or reddened at any time within two weeks after its birth, it shall be the duty of such midwife or nurse having charge of such infant to report such fact in writing, within six hours, to the health officer, or some legally qualified practitioner of medicine in the city, town or district in which the parents of the infant reside. Any failure to comply with the provisions of this act shall be punishable by a fine not to exceed $\$ 100$ or imprisonment not to exceed six months, or both.

Right Denied to Boards of Health.-A health ordinance providing that no cows shall be kept within two hundred feet of any dwelling without a special permit obtained from the board of health, the general term of the Supreme Court of New York holds, in the case of Village of Flushing v. Carraher, decided May 13,1895, is not authorized by a statute which gives local boards of health power to make and publish all such orders and regulations as they may deem necessary and proper for the preservation of life and health and the execution and enforcement of the public health in the municipality, and to make, without publication thereof, orders and regulations for the suppression of nuisances and concerning all other matters in their judgment detrimental to the public health in special or individual cases. Under the statute, if the matter is such that a general ordinance can be passed upon the subject, the court says that then such ordinance should be enacted. If not susceptible of general regulation, then the board should proceed by special order in the particular case, when the person attacked may defend himself in the courts. The board of health, by the ordinance under review, did not forbid the keeping of cows within two hundred feet of a dwelling house, but so keeping cows without a special permit. In other words, the board took to itself the power of licensing cow stables. No such power was granted by the Legislature.
French Degeneracy from Alcoholism - Absinthe Condemned.The Paris correspondent of the Press and Circular, for the issue of June 26, writes that Dr. Lannelongue, who is a member of the House of Deputies as well as professor at the Academy, has made a vigorous appeal against the lax laws of France concerning the manufacture and sale of alcohol. "Among other statements made by Dr. Lannelongue, he said that 'alcoholism, at the present day, was not only endangering the public health, but also threatening the very existence of the species; it filled the hospitals, the asylums, the prisons, and populated the penal settlements. Previous to 1850 , alcoholism was almost unknown, or rather it had not the same character; the effects were temporary because the drink taken was pure and natural. But four years afterward, alcohol of vinous origin failed, and immediately it was replaced by that derived from molasses. beet-root, and potatoes, which poisoned the race. In 1830 the number of suicides from alcoholism were 5 per 100,000 persons; they were 21 in 1881, while 46 per cent. of homicides, 74 per cent. of grievous wounding, 54 per cent. of domestic quarrels, 77 per cent. of outrages against public decency were due to drink. Against the many afflictions which attack man, against the large number of contagious maladies, epidemic or other, the characteristic of the healthy individual is his organic resistance, which enables him to triumph over all the assaults from his most terrible enemies-microbes. 'The drunkard, on the other hand, has lost all resistance, and falls an easy prey to disease. At 40 he is already an old man; his tissues are degenerated, so that he makes the worst of patients. It is not the richer classes in France who saturate their bodies with alcohol, because they know better, but the lower classes, and especially the workmen, who are ill-fed, clothed, and lodged. In Brittany, however, women of good position give themselves up to alcohol. Out of 107 young married women who died from drink 8 were sterile, and of the 99 others there only remained as posterity 6 sickly children. On the other hand, these same women had 28 children before having taken to alcohol who are very healthy, showing what the others might have been if the mothers had led a sober life. What is still worse,' continued Dr. Lannelongue, 'is the fact that the passion of the parents is transmitted to the children. The drunkard engenders an offspring with the same tendency, be they girls or boys, and curious to say, they begin to drink at the same age that the father began to drink." " Dr. Lannelongue, who spoke for nearly two hours, interrupted by frequent applause, concluded by appealing to the government to take under its own control the manufacture of alcohol, and to forbid entirely all those liquors made from essences, and more especially from absinthe.

Health Reports.-The following health reports of infectious diseases have been received by the Supervising SurgeonGeneral of the Marine-Hospital Service:

SMALLPOX-UNITED STATES.

New York: Brooklyn, August 10 to 17,1 case.

Texas: Eagle Pass (smallpox camp), to August 18, 143 cases, 35 deaths.

Tennessee: Memphis, July 1 to August 7, 10 cases ; Shelby County, July 1 to 31,17 cases.

Philadelphia: July 17 to August 16, 18 cases, 1 death. SMALLPOX-FOREIGN.

Antwerp: July 20 to 27,2 cases.

Buda-Pesth: July 22 to 29,2 cases.

Calcutta: June 30 to July 6,6 deatbs.

Guayaquil: July 19 to 26,3 deaths.

Madrid: July 22 to 29,1 death.

Nogales: August 3 to 10,5 cases, 1 death.

Odessa: July 20 to 27,7 cases.

Rio de Janeiro: July 13 to 20,40 deaths.

St. Petersburg: July 20 to 27,1 case.

CHOLERA.

India: Bombay, July 2 to 9, 1 death ; Calcutta, June 30 to July 6, 22 deaths.

Japan: Hiogo, July 13 to 20, 85 cases, 74 deaths; Nagasaki, July 5 to 12,29 cases, 20 deaths.

Russia: Volhynia, June 8 to 22,57 cases, 20 deaths.

Turkey: Mersine, June 18 to July 16, 410 cases, 235 deaths ; 